\title{
EFEK VITAMIN C DALAM MEDIUM DMEM TERHADAP PERTUMBUHAN SEL PARU-PARU FETUS HAMSTER SECARA IN VITRO
}

\author{
Ema Kurnia W, Kholifah Holil
}

Jurusan Biologi, Fakultas Sains dan Teknologi

Universitas Islam Negeri (UIN) Maulana Malik Ibrahim Malang

Email: ema.kurnia58@yahoo.com, ifa_biomolrep03@yahoo.com

\begin{abstract}
Abstrak.
Penelitian ini dilakukan dengan tujuan untuk mengetahui efek vitamin $C$ dalam medium DMEM terhadap pertumbuhan sel paru-paru fetus hamster secara in vitro dan untuk mengetahui pada konsentrasi berapakah vitamin $C$ dalam medium DMEM yang berpengaruh paling efektif terhadap pertumbuhan sel paru-paru fetus hamster secara in vitro. Penelitian ini merupakan penelitian eksperimental dengan 6 perlakuan dan 2 ulangan. Masing-masing perlakuan tersebut adalah vitamin $C$ dengan konsentrasi OmM (kontrol), 5mM, 10mM, 15mM, 20mM, dan 25mM. Vitamin C dengan berbagai konsentrasi tersebut ditambahkan ke dalam medium DMEM dan selanjutnya digunakan untuk menumbuhkan sel paru-paru fetus hamster. Sel paru-paru fetus hamster diisolasi dari fetus hamster berumur 2 hari, ditumbuhkan dalam medium DMEM yang sudah ditambah dengan vitamin $\mathrm{C}$ dengan berbagai konsentrasi dan diinkubasi dalam inkubator $\mathrm{CO}_{2} 5 \%$ pada suhu $37^{\circ} \mathrm{C}$ selama beberapa hari sampai biakan sel-sel tersebut konfluen. Setelah konfluen biakan sel diamati persentase konfluen, viabilitas dan abnormalitas sel. Hasil penelitian menunjukkan bahwa vitamin C dengan konsentrasi OmM (kontrol), $5 \mathrm{mM}, 10 \mathrm{mM}, 15 \mathrm{mM}$, $20 \mathrm{mM}$, dan $25 \mathrm{mM}$ dalam medium DMEM mampu menghasilkan persentase konfluen berturut-turut $50 \%, 65 \%, 72.5 \%, 82.5 \%, 87.5 \%$, dan $92.5 \%$ dan persentase viabilitas sel sebesar $89 \%, 94.5 \%, 94 \%, 93 \%, 94 \%$, dan 96.5\%. Sedangkan konsentrasi vitamin C yang efektif terhadap pertumbuhan sel paru-paru fetus hamster secara in vitro adalah konsentrasi $25 \mathrm{mM}$.

Kata kunci: vitamin c, DMEM, sel paru, hamster, in vitro
\end{abstract}

\section{PENDAHULUAN}

Kesehatan merupakan permasalahan yang penting dalam kehidupan. Tanpa adanya tubuh yang sehat, maka berbagai macam aktivitas sehari-hari dapat terganggu. Adanya pola hidup tidak sehat yang sekarang ini banyak dilakukan oleh masyarakat seperti kecenderungan untuk beralih dari makanan tradisional ke makanan cepat saji dan kebiasaan makan yang berlebihan dapat menjadi salah satu pemicu masalah kesehatan. Sebagaimana firman Allah SWT dalam surat Al-A'raf ayat 31 :



Artinya : Hai anak Adam, pakailah pakaianmu yang indah di setiap (memasuki) mesjid, makan dan minumlah, dan janganlah berlebih-lebihan. Sesungguhnya Allah tidak menyukai orang-orang yang berlebihan (Q.S Al A'raf ayat 31 ).
Menurut Ibnu Jarir bahwa ayat tersebut menjelaskan tentang larangan untuk hidup berlebih-lebihan dalam segala sesuatu. Berlebihlebihan disini menunjukkan terhadap larangan untuk makan yang berlebih-lebihan karena dapat berbahaya bagi pikiran dan tubuh.

Salah satu jenis penyakit yang ditimbulkan oleh pola hidup tidak sehat adalah kanker paru-paru. Kanker ini menjadi masalah besar di bidang kesehatan karena merupakan penyakit yang menempati peringkat kedua sebagai penyebab kematian di dunia setelah penyakit jantung (Asmino, 1993). Kanker (neoplasma) merupakan sel yang memiliki kecepatan proliferasi lebih tinggi dibanding sel normal (Ramanthan, 1992). Penyakit kanker dapat menyerang berbagai macam sel. Salah satu sel yang diserang oleh penyakit kanker adalah sel paru-paru (Asmino, 1993). Penyakit kanker ini dapat diakibatkan oleh sumber karsinogenik dari lingkungan, kebiasaan hidup yang tidak sehat, dan pola makan yang salah. 
Meskipun demikian, penyakit kanker paru-paru ini dapat dicegah dengan cara menghindari faktor penyebab pemicu terjadinya kanker, salah satunya adalah banyak mengkonsumsi makanan yang mengandung vitamin C. Dengan mengkonsumsi vitamin C maka dapat mencegah timbulnya radikal bebas yang menjadi pemicu terjadinya kanker, sehingga pertumbuhan sel kanker dapat dihambat.

Radikal bebas mempunyai sifat reaktifitas tinggi, karena kecenderungan menarik elektron serta dapat mengubah suatu molekul menjadi suatu radikal. Apabila radikal bebas ini kemudian menjumpai molekul lain maka akan membentuk radikal baru lagi, sehingga terjadilah reaksi rantai (chain reaction) dan bersifat merusak. Reaksi rantai tersebut baru berhenti apabila radikal tersebut dapat diredam. Kemampuan ini dimiliki oleh vitamin $\mathrm{C}$ sebagai antioksidan. Vitamin $\mathrm{C}$ akan melepaskan elektronnya dan mengubah radikal bebas menjadi radikal askorbil, kemudian bereaksi dengan ROS terutama dengan radikal hidroksil $(\mathrm{OH})$ dan anion superoksida $\left(\mathrm{O}_{2}\right)$ (Pavlovic, 2005)

Secara in vitro, pertumbuhan sel paruparu agar tidak mengarah pada sel kanker dapat dimonitor dengan cara menambahkan vitamin $\mathrm{C}$ pada media yang digunakan (DMEM). Dengan menambahkan vitamin $\mathrm{C}$ tersebut diharapkan mampu menstimulasi proliferasi sel paru-paru, akan tetapi tidak menyebabkan sel paru-paru tersebut tumbuh menjadi sel kanker. Selain itu penelitian dengan penambahan vitamin $\mathrm{C}$ ini dapat dijadikan model untuk memahami peran vitamin $\mathrm{C}$ dalam pencegahan pertumbuhan sel kanker. Oleh karena itu, penelitian ini penting dilakukan untuk mengetahui efek vitamin $\mathrm{C}$ dalam medium DMEM pada pertumbuhan sel paru-paru secara in vitro yang untuk selanjutnya dapat digunakan sebagai model dalam pencegahan sel kanker.

\section{BAHAN DAN METODE}

Bahan dalam penelitian ini adalah sel paru-paru yang diisolasi dari fetus hamster berumur 2 hari, vitamin C, DMEM (Gibco-BRL), $\mathrm{NaHCO}_{3}$ (Merck), HEPES (USB, Ohio), FBS (Gibco-BRL), penicillin (Meiji Seika, Tokyo), streptomycin (Meiji Seika, Tokyo), $\mathrm{NaCl}$ Fisiologis 0,9\% (Merck), PBS, tripsin, tripan blue, dan parafilm.

Alat yang digunakan dalam penelitian ini adalah multiwell 24 (Iwaki), disposable syringe $10 \mathrm{ml}$ dengan jarum ukuran $21 \mathrm{Gx} 11 / 2$ ", petri dish, blue tip, yellow tip, rak tabung dan tabung reaksi, bunsen, membran filter $0,22 \mu \mathrm{m}$ (millipore), mikroskop elektron, autoklaf, oven, dan inkubator $\mathrm{CO}_{2}$.

\section{Isolasi dan kultur primer sel paru hamster}

Hamster didislokasi kemudian dibedah. Organ paru-paru fetus hamster diambil, dicuci dalam PBS sebanyak 3 kali. Paru-paru dicacah sampai halus dalam $1 \mathrm{ml}$ tripsin dan diinkubasi selama 20 menit. Kemudian sel diambil dengan spuit dan disemprotkan kembali pada cawan petri, dilakukan berulang kali sampai sel menjadi halus dan tidak menggumpal. Setelah itu dimasukkan dalam tabung sentrifugase dengan disaring menggunakan kain nylon berukuran 100 $\mathrm{mm}$. Kemudian ditambah dengan $2 \mathrm{ml}$ DMEM $0 \%$ untuk menghilangkan tripsinnya. Disentrifugase dengan kecepatan $2000 \mathrm{rpm}$ selama 10 menit.

Supernatan dibuang, pellet diambil, dan ditambah $3 \mathrm{ml}$ DMEM 0\%. Disentrifugase dengan kecepatan 2000 rpm selama 10 menit. Supernatan dibuang, pellet diambil dan ditambah $3 \mathrm{ml}$ DMEM 20\%. Disentrifugase dengan kecepatan $2000 \mathrm{rpm}$ selama 10 menit. Supernatan dibuang, disisakan $1,5 \mathrm{ml}$ pellet, pellet dipipeting (dihomogenisasi), pellet diambil $50 \mu \mathrm{l}$ dan dibagi dalam masing- masing sumuran well 24 yang sudah berisi media tanam $20 \%$ dan vitamin C dengan masing-masing konsentrasi. Kemudian diinkubasi selama 6 hari dan diamati 2 hari sekali. setelah itu dilakukan pengamatan pertumbuhan sel paru-paru fetus hamster untuk mengetahui pengaruh vitamin $\mathrm{C}$.

\section{Pengamatan Konfluen Sel Paru-Paru Fetus Hamster}

Sel dikatakan konfluen apabila sel tersebut telah berkembang dan memenuhi Tissue Culture disk, untuk mengamati konfluennya sel alveolar tipe II paru-paru fetus hamster ini digunakan mikroskop inverted, apabila sel tersebut sudah memenuhi Tissue Culture disk maka sel tersebut dapat di passage, caranya dengan dibuang media kemudian diberi tripsin EDTA sebanyak $3 \mathrm{ml}$. pemberian tripsin ini berguna untuk melepaskan sel yang telah menempel didasar Tissue Culture disk, kemudian dikocok pelan dan dibagi hasil tripsinasi menjadi 2, dimasukkan kedalam Tissue Culture disk baru yang telah berisi media dengan $10 \%$ serum dan antibiotik kemudian diinkubasi dalam suhu $37^{\circ} \mathrm{C}$ dengan $5 \% \mathrm{CO}_{2}$. 
Kriteria dari pengukuran konfluenitas sel ini mencakup persentase sel dalam mencapai konfluen. Sel diamati setiap 3 hari sekali, dari setiap pengamatan tersebut dicatat hasilnya dengan menggunakan persentase $0 \%$ apabila sel belum melekat dalam Tissue Culture disk, 25\% ketika sel sudah memenuhi satu perempat Tissue Culture disk, 50\% apabila sel sudah memenuhi setengah dari Tissue Culture disk, $75 \%$ apabila sel telah memenuhi tiga perempat Tissue Culture disk dan 100\% apabila sel telah memenuhi seluruh Tissue Culture disk.

\section{Pengamatan Viabilitas Sel Paru-Paru Fetus Hamster}

Pengamatan viabilitas sel ginjal fetus hamster dilakukan dengan tujuan untuk mengetahui persentase sel yang hidup dengan menggunakan Tripan Blue 0.4\%. Tripan blue tidak mengubah integritas membrane plasma dan memperlambat proses kematian sel. Tripan blue juga memperkecil jumlah sel dan memfasilitasi identifikasi sel yang akan dilihat dengan mikroskop (Bast et al., 1991).

Sel hasil kultur diambil cairannya dan dimasukkan dalam eppendorf. Kemudian disentrifuse dengan kecepatan 13.000 rpm selama 10 menit. Supernatant dibuang dan ditambah PBS. Disentrifuse dengan kecepatan 13.000 rpm selama 10 menit. Pellet diambil dan disimpan. Well yang sudah diambil cairannya diwashing dengan PBS sebanyak 2 kali. Ditripsinasi dengan tripsin EDTA 0,25\% dan diinkubasi selama 20 menit. Kemudian diketuk-ketuk well agar sel lepas dari well dan setelah itu dimasukkan dalam eppendorf. Disentrifuse dengan kecepatan 13.000 rpm selama 10 menit. Dibuang supernatan dan ditambah dengan PBS. Disentrifuse dengan kecepatan $13.000 \mathrm{rpm}$ selama 10 menit. Pellet disisakan $100 \mu 1$, dicampur dengan sisa pellet yang pertama dan ditambah dengan tripan blue. Kemudian dihitung.

Hemositometer dengan gelas penutup dibersihkan dan diletakkan pada mikroskop untuk mencari garis hemositometer terlebih dahulu. Setelah garis ditemukan, Diteteskan suspensi sel pada hemositometer dari tepi gelas penutup, sehingga cairan masuk di bawah gelas penutup. Didiamkan selama 1-2 menit, tidak boleh terlalu lama, sel yang rusak akan menyerap warna. Sel-sel yang rusak bersifat viabel. Di letakkan di bawah mikroskop dengan objektif 20x. Kemudian jumlah sel yang berwarna dan jumlah seluruh sel dihitung. Jumlah sel yang tidak berwarna menunjukkan viabilitas sel, perhitungan viabilitas dilakukan dengan menggunakan rumus (Besta, 2004) :

$\%$ Viabilitas sel $=\left(\sum\right.$ sel yang hidup $/ \sum$ sel $) \mathrm{x}$ 100

\section{Pengamatan Abnormalitas Sel Paru-Paru Fetus Hamster}

Pengamatan abnormalitas sel dilihat berdasarkan morfologi sel yaitu penampakan bentuk sel yang tidak beraturan misalnya pengkerutan pada membran sel dan ukuran sel yang tidak bulat dan bentuk sel yang melebihi sel normal (bentuk sel lebih besar dari bentuk sel normal) atau disebut juga sel raksasa (giant cell).

Data hasil pengamatan konfluen, viabilitas dan abnormalitas sel paru-paru di analisa dengan analisis deskriptif kualitatif. Hasil pengamatan dicatat dalam tabel, untuk menentukan prosentase viabilitas dan abnormalitas sel paru-paru fetus hamster.

\section{HASIL DAN PEMBAHASAN}

\section{Efek Vitamin C terhadap Konfluen Sel Paru- paru Fetus Hamster}

Berdasarkan hasil penelitian dan analisis statistik deskriptif tentang efek vitamin $\mathrm{C}$ dalam medium DMEM pada konfluenitas sel paru-paru secara in vitro, diperoleh data yang menunjukkan bahwa pada vitamin C konsentrasi $25 \mathrm{mM}$ mampu mempercepat konfluenitas sel paru-paru fetus hamster. Hal tersebut menandakan ada pengaruh vitamin $\mathrm{C}$ dalam medium DMEM pada pertumbuhan sel paru-paru secara in vitro seperti disajikan dalam table 4.1 .

Table 4.1 Efek vitamin c dalam medium DMEM pada pertumbuhan sel paru-paru fetus hamster secara in vitro

\begin{tabular}{|c|c|c|c|c|}
\hline \multirow{3}{*}{ Perlakuan } & \multirow{2}{*}{\multicolumn{2}{|c|}{$\begin{array}{c}\text { Konfluen Sel } \\
(\%) \\
\text { Ulangan }\end{array}$}} & \multirow{3}{*}{ Jumlah } & \multirow{3}{*}{ Rata-rata } \\
\hline & & & & \\
\hline & 1 & 2 & & \\
\hline Kontrol & 55 & 45 & 100 & 50 \\
\hline $\mathrm{P}_{1}(5 \mathrm{mM})$ & 60 & 70 & 130 & 65 \\
\hline $\mathrm{P}_{2}(10 \mathrm{mM})$ & 70 & 75 & 145 & 72.5 \\
\hline $\mathrm{P}_{3}(15 \mathrm{mM})$ & 80 & 85 & 165 & 82.5 \\
\hline $\mathrm{P}_{4}(20 \mathrm{mM})$ & 85 & 90 & 175 & 87.5 \\
\hline $\mathrm{P}_{5}(25 \mathrm{mM})$ & 95 & 90 & 185 & 92.5 \\
\hline
\end{tabular}


Berdasarkan hasil penelitian menunjukkan konfluenitas sel paru-paru paling cepat terjadi pada penambahan konsentrasi vitamin C $25 \mathrm{mM}$. Pada kontrol konfluenitas sel pada hari ke 6 hanya mencapai $50 \%$, sedangkan pada konsentrasi $5 \mathrm{mM}$ mencapai $65 \%$, konsentrasi $10 \mathrm{mM}$ mencapai $72.5 \%$, konsentrasi $15 \mathrm{mM}$ mencapai $82.5 \%$ dan pada konsentrasi 20 $\mathrm{mM}$ mencapai $87.5 \%$ sedangkan pada konsentrasi $25 \mathrm{mM}$ mencapai $92.5 \%$. Hal ini menunjukkan bahwa vitamin $\mathrm{C}$ mampu mempercepat proses konfluenitas pada sel paruparu yang dikultur secara in vitro.

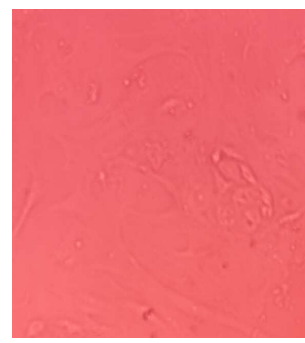

A

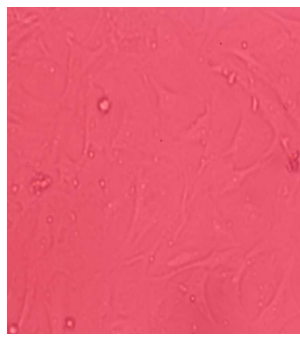

C

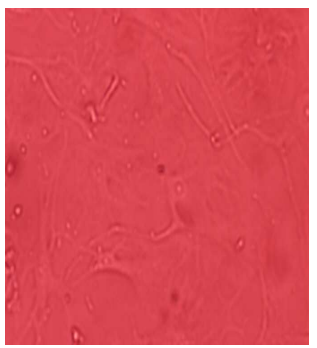

E

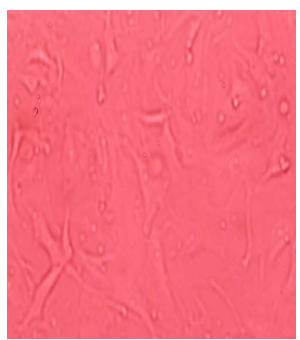

B

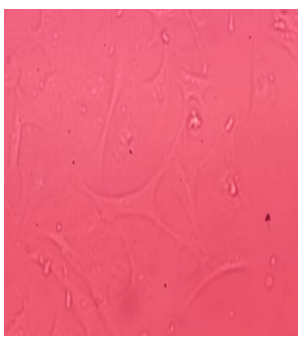

$\mathrm{D}$

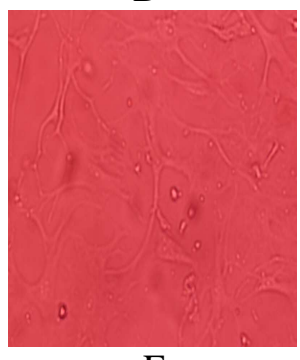

$\mathrm{F}$
Gambar 4.1 Konfluenitas sel paru-paru fetus hamster A. Kontrol, B. Vitamin C 5 mM,C. Vitamin C $10 \mathrm{mM}$, D. Vitamin C 15 mM,E. Vitamin C 20 mM, F. Vitamin C $25 \mathrm{mM}$

Perkembangan sel secara in vitro akan mengalami pertumbuhan yang cepat apabila di dalam medium tersebut terdapat faktor pertumbuhan dan suatu senyawa yang dapat menyeimbangankan kondisi sel (Decker et al., 2000). Ketidakseimbangan kondisi sel dapat menyebabkan sel lambat untuk mencapai konfluen, Karena akan mempengaruhi metabolism sel. Dengan adanya penambahan vitamin C maka kondisi sel dapat terjaga dan metabolisme sel menjadi seimbang, karena Vitamin C merupakan suatu senyawa yang dapat menjaga kondisi sel tetap seimbang, hal ini terkait dengan kemampuam vitamin $\mathrm{C}$ sebagai antioksidan. Mekanisme vitamin C sebagai antioksidan adalah dengan melepaskan elektronnya dan mengubah radikal bebas menjadi radikal askorbil, kemudian bereaksi dengan ROS terutama dengan radikal hidroksil $(\mathrm{OH})$ dan anion superoksida $\left(\mathrm{O}_{2}\right)$ (Pavlovic, 2005). Pada keadaan normal sumber utama radikal bebas adalah kebocoran elektron yang terjadi dari rantai transport elektron, misalnya yang ada dalam mitokondria dan endoplasma retikulum dan molekul oksigen yang menghasilkan superoksida (Decker et al., 2000).

Efek Vitamin C terhadap Viabilitas Sel Paruparu Fetus Hamster

Sel paru-paru yang dikultur secara in vitro menunjukkan pertumbuhan yang bervariasi. Dengan menambahkan vitamin $\mathrm{C}$ pada medium pertumbuhan DMEM sel paru-paru mengalami peningkatan pertumbuhan yang ditunjukkan dengan terjadinya peningkatan persentase viabilitas sel. Data ketersedian persentase viabilitas ini penting untuk dijadikan data pendahuluan sebagai model dalam pencegahan kanker. Kultur sel paru-paru mempunyai bentuk multipolar atau bipolar menyebar pada permukaan cawan kultur. Kultur sel ini setelah konfluen akan menjadi bipolar dan tidak menyebar. Sel yang dapat bermigrasi bipolar atau multipolar seperti sel paru-paru disebut fibroblastik dan sel ini panjangnya lebih dari dua kali lebarnya (Djati, 2006).

Viabilitas sel yang tinggi menunjukkan kemampuan sel tumbuh dan berkembang yang tinggi pula. Peneliti mencoba menambahkan vitamin $\mathrm{C}$ pada konsentrasi tertentu pada media kultur yang bertujuan agar proliferasi sel lebih cepat sehingga ketersediaan sel sebagai model pencegahan kanker lebih berkualitas. Dalam sistem kultur, sel memerlukan media sebagai sumber nutrisi yang berguna untuk proses proliferasi sel. Sel akan mengalami proses pembelahan apabila kebutuhannya terpenuhi. Oleh karena itu pengontrolan media dalam media kultur harus selalu dilakukan sampai sel mencapai konfluen (Djati, 2006).

Vitamin C (asam askorbat) adalah rantai 6 karbon lakton yang dibentuk dari glukosa dalam hepar pada sebagian besar spesies mamalia. Asam askorbat sangat penting pada banyak fungsi fisiologis, diantaranya adalah 
fungsi antioksidan dalam melindungi sel bersama $\alpha$-tokoferol, reduced gluthatione, dan faktorfaktor yang lain. Berdasarkan hasil penelitian pengaruh suplementasi vitamin $\mathrm{C}$ terhadap viabilitas sel paru-paru didapatkan hasil sebagaimana gambar 4.2 dibawah ini :

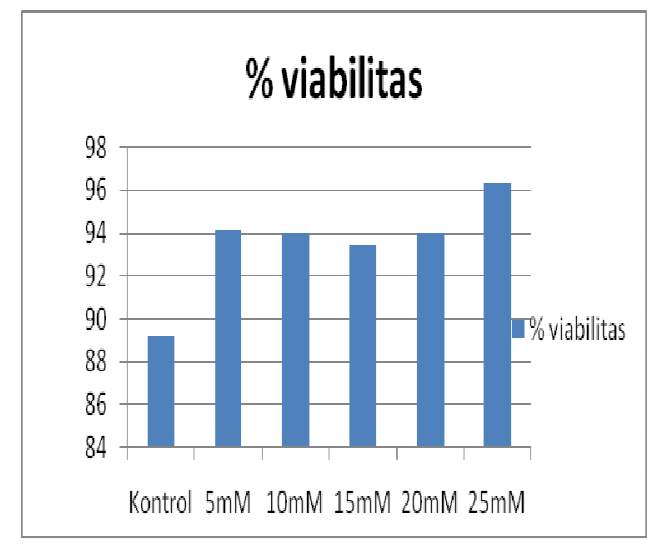

Gambar 4.2 Grafik Rataan Viabilitas kultur sel paruparu hamster dari setiap perlakuan

Grafik di atas menunjukkan bahwa ratarata viabilitas sel tertinggi pada perlakuan vitamin $\mathrm{C}$ konsentrasi $25 \mathrm{mM}$ dan grafik terendah pada kontrol (tanpa penambahan vitamin C). Hal ini menunjukkan bahwa penambahan vitamin $\mathrm{C}$ pada sel paru-paru mampu meningkatkan viabilitas sel. Semakin tinggi konsentrasi penambahan vitamin $\mathrm{C}$ semakin tinggi pula viabilitas sel hasil kultur.

Pengamatan viabilitas sel pada penelitian ini menggunakan tripan blue 0,4\%. Tripan Blue merupakan pewarna yang biasanya digunakan untuk uji viabilitas sel secara sederhana. Tripan blue tidak mengubah integritas membran plasma dan memperlambat proses kematian sel, dan juga memperkecil jumlah sel dan memfasilitasi identifikasi sel yang akan dilihat dengan mikroskop. Sebelum melihat viabilitas sel, lebih dulu ditripsinasi dengan $0,25 \%$ tripsin EDTA agar lebih mudah melakukan perhitungan karena sel akan terpisah-pisah.

Tripsin, kolagenase atau proteinase termasuk enzim proteolitik, biasanya dikombinasikan dengan EDTA, dan menyebabkan sel lepas dari permukaan tempat tumbuhnya. Adanya peningkatan viabilitas sel hasil kultur paru-paru yang diberi perlakuan vitamin C diduga karena sel-sel yang diberi suplementasi vitamin $\mathrm{C}$ lebih tahan terhadap gangguan agen endogenus, sehingga sel-sel tersebut lebih mampu bertahan hidup (viable). Vitamin $\mathrm{C}$ bersifat hidrofilik dan berfungsi paling baik pada lingkungan air sehingga merupakan antioksidan utama dalam plasma terhadap serangan radikal bebas (ROS) dan juga berperan dalam sel. Sebagai zat penyapu radikal bebas, vitamin $\mathrm{C}$ dapat langsung bereaksi dengan superoksida dan anion hidroksil, serta berbagai hidroperoksida lemak (Martini, 1995).

Viabilitas sel yang tinggi menunjukkan proliferasi sel yang tinggi pula. Proliferasi merupakan salah satu parameter yang menunjukkan sel-sel tersebut sehat membelah. Viabilitas sel merupakan perbandingan jumlah sel yang hidup dan sel yang mati. Viabilitas sel ditentukan dari kemampuan sel untuk hidup dan menjalankan metabolismenya dimana ini merupakan faktor yang mempengaruhi keberhasilan kultur sel (Pavlovic, 2005).

Sel-sel yang viable pada penelitian ini ditandai dengan sel yang bening (Gambar 4.2) karena tidak menyerap warna tripan blue, diduga sel tersebut mampu mempertahankan integritas membran sehingga sel tidak terwarnai. Adanya vitamin C pada daerah membran hidrofobik menyebabkan membran sel dapat menjaga integritas membrane.

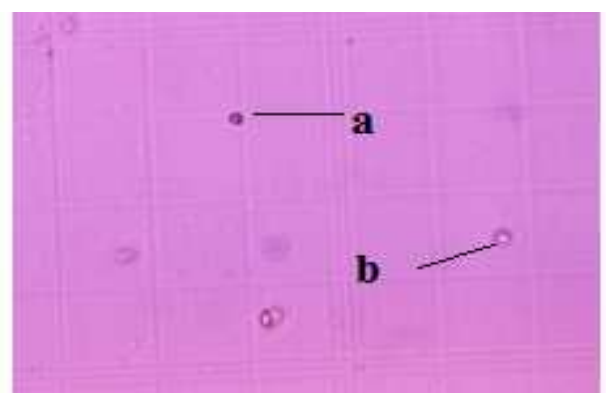

Gambar 4.3 Sel-sel Hasil tripsinasi yang diwarnai dengan tripan blue $0,4 \%$

a. Sel yang mati terlihat terwarnai biru, b. Sel yang viable terlihat bening

Sedangkan sel-sel yang non viable (Gambar 4.2) ditandai dengan sel yang menyerap warna dari tripan blue, hal ini diduga sel tersebut memiliki membran yang rapuh karena vitamin $\mathrm{C}$ belum mampu mempertahankan integritas membran atau karena enzim protease yang diakibatkan tripsin mendegradasi membran sel sehinggan membran sel menjadi rapuh dan mudah dilalui zat- zat ekstrasel termasuk tripan blue.

\section{Efek Vitamin C terhadap Abnormalitas Sel Paru-paru Fetus Hamster}

Berdasarkan hasil penelitian tentang efek vitamin $\mathrm{C}$ dalam medium DMEM pada 
pertumbuhan sel paru-paru secara in vitro sebagai model pencegahan sel kanker menunjukkan bahwa perlakuan $\mathrm{P}_{5}$ atau penambahan vitamin $\mathrm{C}$ dengan konsentrasi $25 \mathrm{mM}$ mampu mengurangi terjadinya pertumbuhan abnormal pada sel paruparu fetus hamster dibandingkan dengan konsentrasi vitamin $\mathrm{C}$ yang lainnya.

Table 4.1 Efek vitamin c dalam medium DMEM pada pertumbuhan sel paru-paru secara in vitro

\begin{tabular}{ccccc}
\hline \multirow{2}{*}{ Perlakuan } & \multicolumn{2}{c}{$\begin{array}{c}\text { Abnormalitas } \\
\text { Sel (\%) }\end{array}$} & \multirow{2}{*}{ Jumlah $\begin{array}{c}\text { Rata- } \\
\text { rata }\end{array}$} \\
\cline { 2 - 3 } & \multicolumn{2}{c}{ Ulangan } & & \\
\hline Kontrol & 6.28 & 6.7 & 12.98 & 6.49 \\
\hline $\mathrm{P}_{1}(5 \mathrm{mM})$ & 5.43 & 6.95 & 12.38 & 6.19 \\
\hline $\mathrm{P}_{2}(10 \mathrm{mM})$ & 3.16 & 5.29 & 8.45 & 4.23 \\
\hline $\mathrm{P}_{3}(15 \mathrm{mM})$ & 3.54 & 2.12 & 5.66 & 2.83 \\
\hline $\mathrm{P}_{4}(20 \mathrm{mM})$ & 0.9 & 1.58 & 2.48 & 1.24 \\
\hline $\mathrm{P}_{5}(25 \mathrm{mM})$ & 0.47 & 0.48 & 0.95 & 0.48 \\
\hline
\end{tabular}

Sel dikatakan abnormal apabila sel tersebut berukuran melebihi ukuran sel normal dan mengalami perubahan bentuk dari asalnya, terkontaminasi oleh bakteri dan jamur (Djati, 2006). Abnormalitas sel yang sering muncul pada kultur sel ditandai dengan adanya sel raksasa ( $\mathrm{sel}$ giant), nekrosis dan blebing.

Hasil penelitian menunjukkan bahwa pertumbuhan sel abnormal yang terlihat pada sel paru-paru adalah nekrosis. Sel paru-paru yang mengalami nekrosis ditandai dengan kerusakan pada membran sel sehingga terjadi keluarnya isi sel. Tanda lain yang menunjukkan bahwa sel tersebut mengalami nekrosis sel adalah adanya inti sel yang lebih gelap. Hasil ini sesuai dengan penelitian bahwa morfologi sel nekrosis adalah kromatin menggumpal, pembengkakan organel, kerusakan membran sel, dan keluarnya isi sel yang bisa menyebabkan inflamasi (Moodie, 2004).

Mekanisme yang menyebabkan pertumbuhan abnormal ini adalah adanya radikal bebas baik karena faktor endogen misalnya hasil dari metabolisme sel atau faktor eksogen misalnya dari media kultur. Radikal bebas tersebut dapat menyebabkan peroksidasi lipid dan rusaknya membran sel serta terdegradasinya protein sehingga menyebabkan peningkatan ion $\mathrm{Ca}^{2+}$. Peningkatan ion $\mathrm{Ca}^{2+}$ akan mengaktifkan enzim perusak DNA seperti protease sehingga terjadi kerusakan pada DNA dan kemampuan DNA untuk repair atau memperbaiki DNA juga rusak sehingga terjadilah pertumbuhan sel yang abnormal.

Apabila kerusakan DNA tidak parah maka masih bisa diperbaiki oleh sistem perbaikan DNA, jika tidak bisa maka replikasi sel akan terganggu. Dalam perbaikan DNA seing terjadi mutasi karena membuat kesalahan yang apabila mengenai gen-gen tertentu maka menimbulkan kanker (Nawasasi, 2003).

Vitamin $\mathrm{C}$ atau L-asam askorbat merupakan antioksidan non enzimatis yang larut dalam air. Senyawa ini merupakan bagian dari sistem pertahanan tubuh terhadap senyawa oksigen reaktif dalam plasma dan sel (Nawasasi, 2003). Asam askorbat berperan sebagi reduktor untuk berbagai radikal bebas. Selain mampu meminimalkan terjadinya kerusakan yang disebabkan oleh stres oksidatif (Foyer, 1993).

Vitamin C (asam askorbat) dapat bereaksi langsung dengan radikal bebas yang sangat reaktif dan larut dalam air, seperti radikal hidroksil dan radikal peroksil. Asam askorbat memberikan satu elektronnya, sehingga radikal bebas yang berbahaya akan menjadi stabil, sedangkan asam askorbat sendiri akan berubah menjadi radikal bebas askorbit yang kurang reaktif dan kemudian dapat direduksi kembali menjadi asam askorbat atau asamdehidroaskorbat (Martini, 1995).

Suhartono et al., (2007) mengemukakan bahwa sebagai zat penyapu radikal bebas dan reduktor asam askorbat akan mendonorkan satu elektron membentuk semidehidroaskorbat yang tidak bersifat reaktif dan selanjutnya mengalami reaksi disproporsionasi membentuk dehidroaskorbat yang bersifat tidak stabil. Dehidroaskorbat akan terdegradasi membentuk asam oksalat dan asam treonat. Oleh karena kemampuan vitamin $\mathrm{C}$ sebagai penghambat radikal bebas, maka peranannya sangat penting dalam menjaga integritas membran sel.

Vitamin C juga menghambat oksidasi lemak dan protein. dan juga untuk meredam kejadian kanker (Stanczyk, 2005). Dengan mengkonsumsi vitamin $\mathrm{C}$ maka dapat mencegah timbulnya radikal bebas yang menjadi pemicu terjadinya kanker, sehingga pertumbuhan sel kanker dapat dihambat sehingga tidak berpengaruh terhadap proliferasi sel khususnya dapat menghindari terjadinya pertumbuhan abnormal pada sel. Nabi bersabda : "Dua nikmat yang sering manusia tertipu olehnya yaitu nikmat sempat dan nikmat sehat." Dari hadist tersebut dapat disimpulkan bahwa kesehatan merupakan permasalahan yang penting dalam kehidupan dan salah satu nikmat dari Allah yang sangat besar. 


\section{KESIMPULAN}

Berdasarkan hasil penelitian dan pembahasan di atas, maka dapat disimpulkan bahwa :

1. Penambahan vitamin $\mathrm{C}$ dalam medium DMEM dapat mempercepat konfluen sel, mempertahankan viabilitas dan mengurangi abnormalitas sel paru-paru fetus hamster.

2. Konsentrasi vitamin $\mathrm{C}$ yang efektif terhadap pertumbuhan sel paru-paru fetus hamster secara in vitro adalah konsentrasi $25 \mathrm{mM}$.

\section{UCAPAN TERIMA KASIH}

Ucapan terima kasih ditujukan kepada Program Penelitian Direktorat Pendidikan Tinggi Islam (DIKTIS) 2010 atas dukungan dana dalam penelitian ini.

\section{DAFTAR PUSTAKA}

Asmino. 1993. Upaya pengobatan penyakit kanker secara konvensional dan alternatif. Simposium IImiah Populer, Bandung

Bast A, Haenen GR, Doelman CJ. Oxidants and antioxidants, state of art. Am Journal Medica 1991;91(3C):2S-13S

Decker, E. A., C. Fautsman and C.J Lopez-Bote. 2000. Antioxidants in Muscle Food. Canada : john Willey and Sons, Inc

Djati, M. S. 2006. Teknologi Manipulasi dan Kultur Sel Jaringan Hewan. Malang : UB Press

Foyer, C. 1993. Scorbic Acid. dalam: Antioxidants in Higher Plants. R.G. Alssher dan J.L. Hess (Eds.) Boca Raton: CPC Press. Pp. 31-58

Martini. 1995. Pengaruh Asap Tembakau Terhadap Status Vitamin $C$ dalam Darah. Surabaya : lembaga Penelitian UNAIR

Moodie, F. M. 2004. Oxidative stress and cigarette smoke alter chromatin remodeling but differentially regulate NF-KB activation and proinflammatory cytokine release in alveolar epithelial cells. The FASEB Journal $2004 ; 18: 189 ; 7-9$

Nawasasi, Lakhsmi. 2003. Efek Pemberian Antioksidan Pada Kerusakan Ginjal Akibat Obstruksi Total Ureter Satu Sisi. (Skripsi). Universitas Diponegoro. Semarang
Pavlovic, V. 2005. Antioxidant and Pro-oxidant Effect of Ascocbic Acid. Acta Medica Medianae. 44 (1): 65-69.

Ramanthan, R. 1992. Cytotoxic Effect of Plant Polyphenols and Fat Soluble Vitamins on Malignant Human Cultured Cells. Cancer letters. 62 (3) : 217-224

Stanczyk, M. 2005. The Effect of Vitamin C and Glutathione on Ethanol Cytotoxcity and Selected Parameters of Pro-and Antioxidative Processes in Mouse Fibroblasts 3T3-LI. Polish Journal of Environmental Studies Vol. 15, No. 1 (2005), 131-137

Suhartono E, Fachir H \& Setiawan B. 2007. Kapita Sketsa Biokimia Stres Oksidatif Dasar dan Penyakit. Universitas Lambung Mangkurat, Banjarmasin: Pustaka Benua 